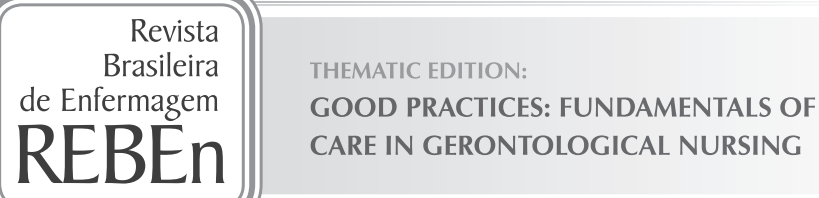

\title{
Evaluation of the safety of hospitalized older adults as for the risk of falls
}

\author{
Avaliação da segurança do idoso hospitalizado quanto ao risco de quedas \\ Evaluación de la seguridad del anciano hospitalizado en cuanto al riesgo de caídas
}

\section{Nathalia de Araújo Sarges ${ }^{1, I I}$, Maria Izabel Penha de Oliveira Santos ${ }^{1, \text { II }}$, Emanuele Cordeiro Chaves ${ }^{I I, I I I}$ \\ 'Universidade do Estado do Pará, Master's in Nursing. Belém, Pará, Brazil. \\ "Universidade do Estado do Pará, Teaching, Research and Extension Group about Aging and Health of Older Adults from Amazônia. Belém, Pará, Brazil. \\ II' Universidade Federal do Pará, Postgradute Program in Tropical Diseases. Belém, Pará, Brazil.}

\begin{abstract}
How to cite this article:
Sarges NA, Santos MIPO, Chaves EC. Evaluation of the safety of hospitalized older adults as for the risk of falls. Rev Bras Enferm [Internet]. 2017;70(4):860-7. [Thematic Edition "Good Practices: Fundamentals of care in Gerontological Nursing"] DOI: http://dx.doi.org/10.1590/0034-7167-2017-0098
\end{abstract}

Submission: 02-14-2017 Approval: 04-19-2017

\begin{abstract}
Objective: To evaluate the safety of hospitalized older adults as for the risk of falls according to the parameters of the Morse Fall Scale. Method: Epidemiological, cross-sectional, prospective and descriptive study with $n=75$. Results: Average age of 71.3 years $(\mathrm{SD} \pm 8.2) ; 58.7 \%$ male; $44 \%$ with low educational level; $38.7 \%$ hospitalized for cardiovascular diseases; average hospitalization of 10 days $(\mathrm{SD} \pm 9.38$ ); $78.7 \%$ with comorbidities; $61.3 \%$ with the calf circumference $\geq 31 \mathrm{~cm} ; 62.7 \%$ were former smokers for more than 10 years; $65 \%$ did not drink alcohol; $100 \%$ did not have identification bracelet; $22.7 \%$ had similar names in the infirmary; $48 \%$ took up to five medicines; and $93.3 \%$ received some invasive procedure, especially the vessel puncture $(65.3 \%)$. There was a high risk of falls in $52 \%$ of older adults. Conclusion: The results pointed to imminent risk of breach of patient safety, emphasizing the need for implementation of protocols and predictive scales such as the Morse scale.

Descriptors: Older Adults; Patient Safety; Accidents by Falls; Nursing Care; Geriatric Nursing.
\end{abstract}

\section{RESUMO}

Objetivo: Avaliar a segurança do idoso hospitalizado quanto ao risco para quedas segundo os parâmetros da Morse Fall Scale. Método: Estudo epidemiológico, transversal, prospectivo, descritivo com $n=75$. Resultados: Média de idade de 71,3 anos ( $\mathrm{DP} \pm 8,2) ; 58,7 \%$ do sexo masculino; $44 \%$ com baixa escolaridade; $38,7 \%$ internados por doenças cardiovasculares; média de internação de 10 dias ( $\mathrm{DP} \pm 9,38) ; 78,7 \%$ com comorbidades; $61,3 \%$ com a circunferência da panturrilha $\geq 31 \mathrm{~cm} ; 62,7 \%$ eram ex-fumantes havia mais de 10 anos; $65 \%$ não ingeriam bebida alcoólica; $100 \%$ não possuíam pulseira de identificação; $22,7 \%$ possuíam nomes similares na enfermaria; $48 \%$ ingeriam até cinco medicamentos; $93,3 \%$ receberam algum procedimento invasivo, principalmente a punção de vaso $(65,3 \%)$. Houve risco elevado para quedas em $52 \%$ dos idosos. Conclusão: Os resultados apontaram risco iminente da quebra de segurança do paciente, ressaltando a necessidade de implementação de protocolos e escalas preditivas, como a escala de Morse.

Descritores: Idoso; Segurança do Paciente; Acidentes por Quedas; Cuidados de Enfermagem; Enfermagem Geriátrica.

\section{RESUMEN}

Objetivo: Evaluar la seguridad del anciano hospitalizado en cuanto al riesgo de caídas según los parámetros de la escala de Morse. Método: Estudio epidemiológico, transversal, prospectivo, descriptivo con $n=75$. Resultados: Promedio de edad de 71,3 años ( $\mathrm{DP} \pm 8,2$ ); $58,7 \%$ del sexo masculino; $44 \%$ con baja escolaridad; $38,7 \%$ internados por enfermedades cardiovasculares; promedio de internación de diez días ( $\mathrm{DP} \pm 9,38$ ); 78,7\% con comorbilidades; $61,3 \%$ con la circunferencia de la pantorrilla $\geq 31 \mathrm{~cm}$; el $62,7 \%$ eran ex fumadores durante más de 10 años; el $65 \%$ no ingería bebida alcohólica; el $100 \%$ no tenía pulsera de identificación; el 22,7\% tenía nombres similares en la enfermería; el $48 \%$ ingería hasta cinco medicamentos; el 93,3\% recibieron algún procedimiento invasivo, principalmente la punción de vaso (65,3\%). Hubo un riesgo elevado de caídas 
en el 52\% de los ancianos. Conclusión: Los resultados apuntaron un riesgo inminente de la quiebra de seguridad del paciente, resaltando la necesidad de implementación de protocolos y escalas predictivas, como la escala de Morse.

Descriptores: Anciano; Seguridad del Paciente; Accidentes por Caídas; Cuidados de Enfermería; Enfermería Geriátrica.

CORRESPONDING AUTHOR Nathália de Araújo Sarges Email: nathdream@hotmail.com

\section{INTRODUCTION}

Brazil is one of the countries that compose the World Alliance for Patient Safety. In 2013, the Brazilian Ministry of Health prepared and issued the Ministerial Order 529, which established the Programa Nacional de Segurança do Paciente (National Patient Safety Program - PNSP), which defines the relevant concepts in the area and key strategies for the implementation of PNSP(1).

It is known that, in Brazil, there are over 200,000 assistance health establishments, in which patients are routinely exposed to technologies in health and professional assistance interventions, being subjected, therefore, to adverse events (AEs). The adverse event is an incident that results in unintentional damage resulting from assistance and not related to the natural evolution of the base disease of the patient ${ }^{(2)}$.

Among the strategies for reduction of security incidents, the prevention of falls during hospitalization is one of the goals established by PNSP(1). Falls during hospitalization are one of the most important occurrences in breach of patient safety and are often responsible for the increase in the number of days of hospitalization and worse recovery conditions. In addition, falls are not evenly distributed in hospitals, being more frequent in units with many older patients, in neurology and rehabilitation. Hence, this has been a topic of research, study and intervention in healthcare facilities ${ }^{(3)}$.

There are several scales designed for evaluation of risk of falls, such as the Berg Balance Scale (EEFB), which assesses the development of functional tasks; the Timed Up and Go (TUG) scale, which evaluates basic mobility of the person; and the Morse Fall Scale, which stands out because of the apparent simplicity of their assessment items, being recommended by PNSP(1,4).

The Morse Falls Scale is a scale originally in English, created by Janice Morse, in 1989, which authorized, in 2013, the translation, adaptation and validation in Brazil. This scale assesses the risks of falls as potential danger in the security of hospitalized older adults and has six domains (history of falls, secondary diagnosis, assistance in ambulation, use of intravenous devices, gait and mental state) $)^{(4)}$.

Older adults consume more healthcare services, hospital admissions are more frequent, and the bed occupancy time is greater than that of patients of other age groups, and that does not mean more benefits. In general, diseases of older adults are chronic and multiple, lasting for several years and requiring medical follow-up and permanent multidisciplinary teams and frequent hospitalizations ${ }^{(5)}$.

In this context, the main focus of this study was the evaluation of the safety of hospitalized older adults as for the risk of falls, in view of the great demand of older adults seeking assistance with medium and high complexity institution and the implications that prolonged hospitalizations can bring to their health. The study aimed to assess the safety of hospitalized older adults as for the risk for falls according to the parameters of the Morse Fall Scale.

\section{METHOD}

\section{Ethical aspects}

The survey was submitted and approved by two committees of ethics in research with human beings, of the Universidade do Estado do Pará (UEPA) and the hospital where the study was conducted. Older adults and their companions have signed the informed consent form, as recommended in the Ministerial Order 466/2012.

\section{Study design, local and period}

Cross-sectional, epidemiological, prospective and descriptive type of study, held in a public hospital in Belém, Pará. The eligible nurseries for assessment of older adults were the medical clinic and cardiology because they receive the highest number of patients aged 60 years old or over. Data collection took place from June 2015 to July 2016.

Population and sampling, inclusion criteria and variables

It were selected for the study, seniors who were hospitalized for more than 72 hours. The delimitation of the sample was based on the number of hospitalizations in 2014, N=216 older adults; after sample calculation $\left(n=N \cdot n_{o} N+n_{o^{\prime}} \text { where } n_{o}=1 / E^{2}\right)^{(5)}$; considering $10 \%$ alpha value, the estimated sample was $n=68$ older adults, and the final sample was $n=71$ older adults. The independent variables of the study were divided into sociodemographic: age, sex, origin, income and level of education; epidemiological, health variables: reason for admission, readmission number, time of hospitalization, comorbidities, complications, invasive procedure, smoking, alcoholism, calf circumference, number of medicines in use, ID bracelet, similar names in the infirmary; and the outcome variable was the "risk of falls" according to the Morse Fall Scale.

\section{Study protocol}

For data collection, we used two protocols. The first was created by the researchers of this study and contemplated sociodemographic, epidemiological and health variables. The second protocol was the scale of assessment of the risk of falls, i.e., the Morse Fall Scale.

Sociodemographic, epidemiological and health variables were obtained from the individual medical record of the older adults. From the medical record, we also obtained the information to fill items 1 and 2 of the Morse Fall Scale; the other items of the scale were observed in the infirmary and registered in the research protocol (Figure 1). Evaluation of scale parameters meet the following domains (history of falls, secondary diagnosis, assistance in ambulation, use of intravenous devices, gait and mental state), each rated domain receives a score ranging from 0 to 30 points, totaling a risk score, whose classification is as follows: low risk 0-24; medium risk, 25-44; and high risk $\geq 45^{(4)}$. 


\begin{tabular}{|c|c|c|}
\hline \multicolumn{3}{|c|}{ Morse Fall Scale - Língua Portuguesa } \\
\hline Itens & Definicão Operacional & Pontos \\
\hline \multicolumn{3}{|c|}{ 1. Histórico de quedas } \\
\hline Não & $\begin{array}{l}\text { Se o paciente não tem história de quedas nos últimos } \\
\text { três meses. }\end{array}$ & 0 \\
\hline Sim & $\begin{array}{l}\text { Se o paciente caiu durante o período da internação } \\
\text { hospitalar ou se tem um histórico recente (até três } \\
\text { meses) de quedas por causas fisiológicas, tais como } \\
\text { convulsões ou marcha comprometida antes da } \\
\text { admissão hospitalar. }\end{array}$ & 25 \\
\hline \multicolumn{3}{|c|}{ 2. Diagnóstico secundário } \\
\hline Não & $\begin{array}{l}\text { Se no prontuário do paciente apresentar apenas um } \\
\text { diagnóstico médico. }\end{array}$ & 0 \\
\hline Sim & $\begin{array}{l}\text { Se no prontuário do paciente apresentar mais de um } \\
\text { diagnóstico médico. }\end{array}$ & 15 \\
\hline \multicolumn{3}{|c|}{ Morse Fall Scale - Língua Portuguesa } \\
\hline Itens & Definicão Operacional & Pontos \\
\hline \multicolumn{3}{|c|}{ 3. Auxílio na deambulação } \\
\hline $\begin{array}{l}\text { Nenhum/ } \\
\text { Acamada/ } \\
\text { Auxiliado por } \\
\text { Profissional da } \\
\text { Saúde }\end{array}$ & $\begin{array}{l}\text { Se o paciente deambula sem equipamento auxiliar } \\
\text { (muleta, bengala ou andador), se deambula com a } \\
\text { ajuda de um membro da equipe de saúde, ou ainda } \\
\text { se usa cadeira de rodas ou se está acamado e não sai } \\
\text { da cama sozinho. }\end{array}$ & 0 \\
\hline $\begin{array}{l}\text { Muletas/ } \\
\text { Bengala/ } \\
\text { Andador }\end{array}$ & Se o paciente utiliza muletas, bengala ou andador. & 15 \\
\hline $\begin{array}{l}\text { Mobiliário/ } \\
\text { Parede }\end{array}$ & $\begin{array}{l}\text { Se o paciente se movimenta apoiando-se no } \\
\text { mobiliário/paredes. }\end{array}$ & 30 \\
\hline \multicolumn{3}{|c|}{ 4. Terapia endovenosa/dispositivo endovenoso salinizado ou heparinizado } \\
\hline Não & $\begin{array}{l}\text { Se o paciente não usa dispositivo endovenoso. } \\
\text { Nota: quando o paciente usa dispositivo totalmente } \\
\text { implantado, considera-se pontuação zero, quando } \\
\text { não estiver em uso. }\end{array}$ & 0 \\
\hline Sim & $\begin{array}{l}\text { Se o paciente usa dispositivo endovenoso com } \\
\text { infusão contínua ou não (salinizado ou heparinizado) }\end{array}$ & 20 \\
\hline
\end{tabular}

\begin{tabular}{|c|c|c|}
\hline \multicolumn{3}{|c|}{ Morse Fall Scale - Língua Portuguesa } \\
\hline Itens & Definicão Operacional & Pontos \\
\hline \multicolumn{3}{|l|}{ 5. Marcha } \\
\hline $\begin{array}{l}\text { Normal/ Sem } \\
\text { deambulação, } \\
\text { Acamado, } \\
\text { Cadeira de } \\
\text { Rodas }\end{array}$ & $\begin{array}{l}\text { Uma marcha normal é caracterizada pelo andar de } \\
\text { cabeça ereta, braços balançando livremente ao lado do } \\
\text { corpo e passos largos, sem hesitação. Também recebe a } \\
\text { mesma pontuação se o paciente está acamado e/ou usa } \\
\text { cadeira de rodas (sem deambulação). }\end{array}$ & 0 \\
\hline Fraca & $\begin{array}{l}\text { Os passos são curtos e podem ser vacilantes. Quando } \\
\text { a marcha é fraca, embora o paciente incline-se para } \\
\text { frente, enquanto caminha, é capaz de levantar a cabeça } \\
\text { sem perder o equilíbrio. Além disso, caso ele faça uso } \\
\text { de algum mobiliário, como apoio, este apoio se dá de } \\
\text { maneira leve somente para se sentir seguro, não para se } \\
\text { manter ereto. }\end{array}$ & 10 \\
\hline $\begin{array}{l}\text { Comprometida/ } \\
\text { Cambaleante }\end{array}$ & $\begin{array}{l}\text { O paciente dá passos curtos e vacilantes e pode } \\
\text { ter dificuldade de levantar da cadeira, necessidade } \\
\text { de apoiar-se nos braços da cadeira para tevantar e/ } \\
\text { ou impulsionar o corpo (faz várias tentativas para } \\
\text { se levantar impulsionando o corpo). Com esse tipo } \\
\text { de marcha, a cabeça do paciente fica abaixada e } \\
\text { ele ollha para o chão. Devido à falta de equilíbrio, } \\
\text { o paciente agarra-se no mobiliário, em uma pessoa } \\
\text { ou utiliiza algum equipamento de auxílio à marcha } \\
\text { (muletas, bengala, andadores) para segurar-se e não } \\
\text { consegue caminhar sem essa ajuda. Quando ajuda } \\
\text { estes pacientes a caminhar, o membro da equipe de } \\
\text { saúde nota que o paciente realmente se apoia nele e } \\
\text { que, quando o paciente se apoia em um corrimão ou } \\
\text { mobília, ele o faz com força até que as juntas de seus } \\
\text { dedos das mãos fiquem brancas. }\end{array}$ & 20 \\
\hline \multicolumn{3}{|c|}{ Morse Fall Scale - Língua Portuguesa } \\
\hline Itens & Definicão Operacional & Pontos \\
\hline \multicolumn{3}{|l|}{ 6. Estado mental } \\
\hline $\begin{array}{l}\text { Orientado/ } \\
\text { Capaz } \\
\text { quanto à sua } \\
\text { capacidade/ } \\
\text { limitação }\end{array}$ & $\begin{array}{l}\text { Ao perguntar ao paciente "Você é capaz de ir ao } \\
\text { banheiro sozinho ou precisa de ajuda?" verifique se a } \\
\text { resposta é consistente com as informações constantes } \\
\text { no prontuário e/ou com sua avaliação. Em caso } \\
\text { positivo, o paciente é classificado como capaz. }\end{array}$ & 0 \\
\hline $\begin{array}{l}\text { Superestima } \\
\text { capacidade/ } \\
\text { Esquece } \\
\text { limitações }\end{array}$ & $\begin{array}{l}\text { Ao perguntar ao paciente "Você é capaz de ir ao } \\
\text { banheiro sozinho ou precisa de ajuda?" verifique se } \\
\text { a resposta não é consistente com as informações do } \\
\text { prontuário e/ou com sua avaliação ou se a avaliação do } \\
\text { paciente é irreaL Se isto acontecer, este paciente está } \\
\text { superestimando suas habilidades e esquecendo suas } \\
\text { limitações. }\end{array}$ & 15 \\
\hline
\end{tabular}

Source: Scale adapted and translated to Portuguese language by Urbanetto, 2013 $3^{(4)}$

Figure 1 - Morse Fall Scale validated in Brazil, 2013

\section{Data analysis and statistics}

For analysis of the obtained data, we built an electronic database in the statistical program SPSS, version 24.0. Then, these data were statistically processed by parametric and nonparametric tests, as simple frequency distribution, measures of dispersion (average and standard deviation), considering the $p$ value $\leq 0.10$.

\section{RESULTS}

Most seniors were aged between 60 and 70 years old, male, born in Belém, Pará, Brazil; There was a predominance of those who received up to a minimum wage and with low level of education (Table 1).

According to Table 2, it is highlighted that, in most seniors of the sample, the main cause of hospitalization were diseases of the cardiovascular system. Between the comorbidities, hypertension was the most prevalent. There was change in calf circumference in about $40 \%$ of the older adults; $57.3 \%$ of the older adults were long-time smokers.
Table 1 - Sociodemographic data of older adults who participated in the study, Belém, Pará, Brazil, $2016(\mathrm{~N}=75)$

\begin{tabular}{|c|c|c|}
\hline Variables & f & $\%$ \\
\hline \multicolumn{3}{|l|}{ Sex } \\
\hline Male & 44 & 58.7 \\
\hline Female & 31 & 41.3 \\
\hline \multicolumn{3}{|l|}{ Age group } \\
\hline $60-70$ & 39 & 52.0 \\
\hline $71-80$ & 28 & 37.3 \\
\hline $81-90$ & 08 & 10.7 \\
\hline
\end{tabular}

Average (71.3)

Standard deviation $( \pm 8.2)$

Origin

Belém

Other municipalities

Has income

Yes

No 
Table 1 (concluded)

\begin{tabular}{lcc}
\hline Variables & $\mathbf{f}$ & $\mathbf{\%}$ \\
\hline Income & & \\
Up to one minimum wage & 45 & 60.0 \\
1-3 minimum wages & 17 & 22.7 \\
4 or + minimum wages & 4 & 5.3 \\
Education level & & \\
Never studied & 12 & 16.0 \\
1 to 3 years of study & 33 & 44.0 \\
4 to 8 years of study & 24 & 32.0 \\
9 years of study or more & 06 & 8.0 \\
\hline
\end{tabular}

Source: Individual medical record.

Table 2 - Epidemiological and health data of the older adults who participated in the study, Belém, Pará, Brazil, $2016(\mathrm{~N}=75)$

\begin{tabular}{|c|c|c|}
\hline Variables & $f$ & $\%$ \\
\hline \multicolumn{3}{|l|}{ Reason for admission } \\
\hline Cardiovascular system diseases & 29 & 38.7 \\
\hline Gastrointestinal system diseases & 25 & 33.3 \\
\hline Respiratory system diseases & 06 & 08.0 \\
\hline Diseases of other systems* & 15 & 20.0 \\
\hline \multicolumn{3}{|l|}{ Comorbidities } \\
\hline Yes & 59 & 78.7 \\
\hline No & 16 & 21.3 \\
\hline \multicolumn{3}{|l|}{ Type of comorbidities } \\
\hline $\mathrm{SAH}^{* *}$ & 22 & 29.3 \\
\hline $\mathrm{DM}^{* *}$ & 07 & 09.3 \\
\hline $\mathrm{SAH}+\mathrm{DM}$ & 26 & 34.7 \\
\hline Others & 04 & 05.3 \\
\hline \multicolumn{3}{|l|}{ Complications during hospitalization } \\
\hline Yes & 16 & 21.3 \\
\hline No & 59 & 78.7 \\
\hline \multicolumn{3}{|l|}{ Type of complication } \\
\hline Infection & 6,0 & 8.0 \\
\hline Pressure injury & 3,0 & 4.0 \\
\hline Others*** & 7,0 & 9.3 \\
\hline \multicolumn{3}{|l|}{ Type of surgical procedure } \\
\hline Amputation & 01 & 1.3 \\
\hline Colostomy & 01 & 1.3 \\
\hline Appendectomy & 01 & 1.3 \\
\hline Tracheostomy & 01 & 1.3 \\
\hline \multicolumn{3}{|l|}{ Calf circumference $* * * *$} \\
\hline$<31 \mathrm{~cm}$ & 29 & 38.7 \\
\hline$\geq 31 \mathrm{~cm}$ & 46 & 61.3 \\
\hline \multicolumn{3}{|l|}{ Number of admissions } \\
\hline $1-3$ & 62 & 82.7 \\
\hline $4-6$ & 11 & 14.7 \\
\hline$>6$ & 02 & 2.7 \\
\hline
\end{tabular}

Source: Individual medical record.

Notes: *Diseases of other systems: Decompensated diabetes mellitus, Pain to be specified, Erysipelas Bullosum, Infection to be specified, Septicemia, Aplastic Anemia, Hemorrhagic Syndrome, Osteomyelitis, Pemphigus. ${ }^{* * S A H}=$ Systemic Arterial Hypertension, DM = Diabetes Mellitus; $* * *$ Other types of complications: Delirium, Liver Cirrhosis, Dyspnea, Seizure, Bleeding, Immobility Syndrome; ****Evaluated in the older adult.
As observed in Table 3, the patient identification bracelets were absent in $100 \%$ of the older adults as well as the similarity of names was present in the same nursery at about $22.7 \%$ of the cases. About $52 \%$ of them made use of polypharmacy. Of the older adults, $93.3 \%$ have undergone some kind of invasive procedure, including puncture of any vessel (65.3\%).

In Table 4, it is observed that, according to the parameters of the Morse scale, there was a high risk for falls in most older adults of the sample.

Table 3 - Distribution of the variables related to the safety of older adults during hospitalization, Belém, Pará, Brazil, $2016(\mathrm{~N}=75)$

\begin{tabular}{lcc}
\hline Variables & $\mathbf{f}$ & \% \\
\hline $\begin{array}{l}\text { ID bracelet } \\
\text { Yes }\end{array}$ & 0 & 0.00 \\
No & 75 & 100 \\
Similar names in the same nursery & & \\
Yes & 17 & 22.7 \\
No & 58 & 77.3 \\
Number of medicines & & \\
1-5 & 36 & 48.0 \\
6-10 & 26 & 34.7 \\
$>10$ & 13 & 17.3 \\
Undergone invasive procedure & & \\
Yes & 70 & 93.3 \\
No & 05 & 06.7 \\
Invasive procedure type & & \\
Vessel puncture & & \\
Bladder catheter & 49 & 65.3 \\
Gastric catheter & 14 & 18.7 \\
Others & 03 & 4.0 \\
\end{tabular}

Source: Individual medical record.

Table 4 - Classification of older adults regarding the risk of falls by the Morse scale during hospitalization, Belém, Pará, Brazil, $2016(\mathrm{~N}=75)$

\begin{tabular}{ccc}
\hline Variable & f & \% \\
\hline Morse Score* & & \\
Low risk & 14 & 18.7 \\
Moderate risk & 22 & 29.3 \\
High risk & 39 & 52.0 \\
Total & 75 & 100 \\
\hline
\end{tabular}

Notes: *Scores of the scale: 0-24, low risk; 25-44, moderate risk; > 45 high risk

\section{DISCUSSION}

Results of this study showed that the sample of older adults presented the average age of 71.3 years, a result similar to other studies on older adults hospitalized in Pará and in the Northeast region of $\mathrm{Brazi}^{(6-7)}$. On the other hand, in research 
done with older adults hospitalized in Rio Grande do Sul, south region of Brazil, the average age was 81 years $^{(8)}$. This difference between regions is because in the North and Northeast regions, despite the continuous aging observed in the last two decades, there is still a fairly young population, due to high levels of fertility in the past. On the other hand, the South region is the area with the lowest concentration of young people. Rio Grande do Sul is the leader among the states with the largest number of older adults: almost $20 \%$ of its inhabitants have more than 60 years old, besides having greater life expectancy $^{(9)}$.

On the relationship between age and risk of falls, the age above 60 years is considered as the largest risk factor important for fall and for the injuries arising from the event. This may be explained by changes in the physiological process of aging that are predictors of falls such as: problems on physical mobility, including postural instability and gait changes, decreased functional, cognitive and visual capacity. In addition, chronic-degenerative diseases and the concomitant use of several medicines are common conditions in older adults and it can also increase the risk of falling ${ }^{(10)}$. Strengthening the association between age and risk of falls, the NANDA International Nursing Diagnosis - NANDA I considers the age above 65 years to the nursing diagnosis "risk of falls"(11).

Most of the older adults of the sample were male (58.7\%), a result similar to that found in other studies on hospitalized older adults ${ }^{(08,12)}$. The predominance of hospitalized men can be explained by several factors, including the fact that there is a significantly higher search of women for primary health care, which can be justified by the values of culturally constructed masculinity, for aspects related to work and mode of operation of health services and their teams. In addition, the increased frequency of hospitalization of older males may be related to the practice of negative attitudes by men such as drinking and smoking habits, lack of physical exercise and the late search for medical assistance ${ }^{(9,13)}$.

In studies carried out in the community, female is the sex that appears most often as a predictor of falls, whereas in hospitals, the results varied in relation to the greater prevalence of falls between sexes ${ }^{(14)}$.

Most of older adults of this study were from Belém, with income of up to one minimum wage. The income level of older adults is a powerful social determinant of health, which, interrelated with precarious housing, food and medicine insecurity, among others, can adversely affect the health of Brazilian older adults and become one of the main factors of premature morbidity and mortality. This probably contributes to increase the statistics of attendance in medium and high complexity level on health care $^{(15)}$.

Regarding education, $41.8 \%$ of older adults had from 1 to 3 years of study, a result similar to that found in other studies in Pará and in other states of Brazil(4,16-18). Senior citizens with low levels of education are less concerned about health care, and have less capacity of involvement in the health recovery, which ends up increasing the risk of falls. The education has an indirect connection with the risk of falls in older adults, since it is related to the lifestyle and quality of life of the individual, and these factors predispose to the risk of falls ${ }^{(19-20)}$.

In this study, $38.7 \%$ of the older adults were admitted for cardiovascular system diseases; and for gastrointestinal system diseases, $33.3 \%$. Among the cardiovascular diseases, there was a predominance of congestive heart failure - CHF $(34.7 \%)$. Results showed that the most prevalent comorbidities were arterial hypertension and diabetes mellitus. Studies on older adults hospitalized in Brazil, in its majority, showed cardiovascular system diseases as the main causes of hospitalization $^{(4,8,16,18)}$. Circulatory diseases are the leading cause of hospitalization of the older adults on the public network and hospitals affiliated to the Brazilian Unified Health System SUS and are highlighted as the main cause of death in this population $^{(21)}$.

An ecological study identified, in the last 50 years, an increase in the mortality rate for cardiovascular diseases in the North and Northeast regions, concurrently to its decrease in the South, Southeast and Midwest regions; the authors relate this elevation of mortality to the improvement in the quality of the information, consequence of the increased surveillance actions and health care in these regions ${ }^{(22)}$.

A meta-analysis study on the relationship between orthostatic hypotension and CHF, with a total of 51,270 individuals and 3,603 incident cases of CHF, suggested that the association between low blood pressure and incidence of $\mathrm{CHF}$ seemed to be significant in middle-aged individuals with hypertension and/or diabetes, but not significant in older individuals without hypertension or diabetes. The results of the authors support our results, according to which the older adults had as main reason of hospitalization the $\mathrm{CHF}$ and the main comorbidities being hypertension and diabetes mellitus, which seems to have influenced at high risk for falls ${ }^{(23)}$.

According to the NANDA-I, changes resulting from cardiovascular problems are included in the risk factor for the nursing diagnosis "risk of falls" in the domain named "physiologic changes." NANDA-I considers the presence of vascular disease, orthostatic hypotension, presence of acute disease and dizziness as risk factors for falling ${ }^{(11)}$.

Among the older adults of the sample, the main complications were infection and pressure injuries, present in $12 \%$ of hospitalized seniors, and are considered to be adverse events in health care. The high number of phlebitis and excessive development of pressure injuries, in an inpatient clinic unit can be associated with the inadequate number of nursing professionals to meet the needs of patients' care; in other words, the lack of human resources in the health service is related to the increase of injuries, mainly among the older adults ${ }^{(24)}$.

Among the older adults of the sample, $82.7 \%$ had been hospitalized at least three times, with an average of 10 days of hospitalization. The time of hospitalization and readmission are considered major risk factors for the functional loss in the older adults. A study conducted in Chicago, with older adults before and after hospitalization, identified that the level of cognitive decline of many older patients increased significantly after a stay in hospital, affecting their reasoning and memory. It is normal for they to have some loss in this 
phase of life, but in hospitalized older adults, the loss more than doubled. According to the authors, from the cognitive point of view, after hospitalization, it was as if people would be 10 years older than they were, especially those who already had some cognitive decline and more severe chronic diseases $^{(25)}$.

As for smoking habits, $62.7 \%$ of older adults were former smokers; with time of smoking greater than 10 years, $44 \%$. In a study conducted in the state of São Paulo, the prevalence of smokers was higher among men, who did not practice physical activity and who had a history of stroke, cancer and chronic lung disease ${ }^{(26)}$. About alcoholic beverage consumption, $65.3 \%$ did not drink. However, among those who reported consuming alcohol, $20 \%$ said to drink often. Older adults who consume alcohol are more willing to have depression and irritability; alcoholism alters liver function of the older adult, leading to cirrhosis and liver failure, as well as increase the risk for falls and death ${ }^{(27)}$.

In this study, it was observed that the hospital did not use ID bracelets in the older adults during the period of hospitalization. In addition, $17 \%$ had similar or identical names in the same nursery. According to the National Health Surveillance Agency Brazil - ANVISA, patients with the same or similar names, when admitted in the same room, are likely sources of incidents relating to exchange of medicines, tests, surgical procedures and exchange of information in shift of duty. Patients themselves can also be the cause of the occurrence of errors, by using documents from other people to access the service or even by providing inaccurate information when questioned about their name ${ }^{(2)}$.

Regarding the number of medicines used by older adults, $48 \%$ had from one to five medicines prescribed for use. The Iberoamerican Center for the Third Age considers the consumption of five or more medicines as polypharmacy ${ }^{(28)}$. Prospective study conducted with older adults hospitalized in inpatient care units, of three hospitals in Mato Grosso, Brazil, found among the predictors of falls during hospitalization: low level of education, polypharmacy and the use of laxatives and antipsychotics ${ }^{(20)}$.

About $93.3 \%$ of older adults held some kind of invasive procedure during hospitalization and, among them, the main cause was the puncture for intravenous or venoclysis device. The use of intravenous devices has the potential to cause harm to the patient and is associated with morbidity and mortality, especially during the hospitalization, because it is conducive to direct or indirect patient contamination by micro-organisms and to infection, which is one of the leading and most serious iatrogenic $\mathrm{C}^{(29)}$.

The results showed: about $52 \%$ of older adults hospitalized who were part of this study had high risk for falls according to the Morse scale score. In South Korea, 50\% of patients had high risk of falls ${ }^{(30)}$. In a study conducted with patients from 18 to 88 years old in a hospital in Spain, it was assessed the risk of falls and then the falls that occurred throughout hospitalization. The authors found only $19 \%$ of patients with high rate of falls by the Morse scale, however, when assessing the falls that occurred, $52.8 \%$ were in the older adults assessed, indicating the need for monitoring of nursing staff, as well as the implementation of preventive measures ${ }^{(31)}$.

In a study carried out in Porto Alegre, Brazil, the high and moderate risk for falls are associated to the occurrence of falls, demonstrating that the falls, in the hospital environment, are capable of prevention by identifying from the Morse scale ${ }^{(32)}$.

\section{Limitations of the study}

The main limitation found in the development of the study was the small sample, due to the long period of permanence of the older adult in hospital, which limits the generalization of the results. But, despite this, it is believed that the results of this study may encourage further research in the area of gerontological nursing and patient safety.

\section{Contributions to the field of nursing, health or public policy}

The risk of falls assessment protocol used here proved to be practical and fast for the nurse to apply in older adults and low cost to the hospital environment. It should be noted that the assessment and management of risk of falls in hospitalized older adults by nursing can significantly reduce mortality, readmissions, the time of stay as well as individual and institutional costs. The results of this study may encourage further research in the area of patient safety and care quality management.

\section{CONCLUSION}

Older adults that participated in the study showed high risk for falls. It is possible to identify that the risk assessment for falls of hospitalized patients, through the Morse scale, tends to improve the nursing care and assists in the first phase of the nursing process, serving as a subsidy for subsequent stages, in addition to qualify the assistance provided by the team and, consequently, the quality rates of the hospital.

Based on the results, it is recommended that the health teams of the hospitals follow the measures for the prevention of falls in hospitalized patients, and it is important that the implementation of protocols and predictive scales, such as the Morse scale, use a flowchart of risk. It is also relevant the report of falls in such a way that they can be identified, in addition to the intrinsic causes, the specific causes of the hospital, such as the environment and the performance of professionals, and so that the culture of patient safety can be widely disseminated.

It should be noted that prevention and management of the risk of falls in older adults are directly linked to nursing care. Research and continuing education in the area of falls in older adults in the hospital environment can make the nurse an expert in this subject, improving the training quality of professionals as well as the level of evidence for the care of older people.

\section{FUNDING}

The project is funded by the Chamada UniversalMCTI/ CNPQ no. 14/2014. Process 45157/2014-3. 


\section{REFERENCES}

1. Brasil. Agência Nacional de Vigilância Sanitária (ANVISA) Ações de vigilância sanitária para segurança do paciente em serviços de saúde [Internet]. 2013 [cited 2016 Jul 16]. Available from: http://portal.anvisa.gov.br

2. Brasil. Agência Nacional de Vigilância Sanitária (ANVISA). Segurança do paciente e qualidade em serviços de saúde [Internet]. 2013 [cited 2015 Sep 30]. Available from: http://www.anvisa.gov.br/hotsite/segurancadopaciente/index.html.

3. Abreu C, Mendes A, Monteiro J, Santos RF. Falls in hospital settings: a longitudinal study. Rev Latino-Am Enfermagem [Internet]. 2012 [cited 2015 Sep 30];20(3):597-603. Available from: http://www.scielo.br/pdf/rlae/v20n3/a23v20n3.pdf

4. Urbanetto JS, Creutzberg M, Franz F, Ojeda BS, Gustavo AS, Bittencourt HR et al. Morse Fall Scale: tradução e adaptação transcultural para a língua portuguesa. Rev Esc Enferm USP [Internet]. 2013 [cited 2015 Sep 30];47(3):569-75. Available from: http://www.scielo.br/pdf/reeusp/v47n3/en_0080-6234-reeusp-47-3-00569.pdf

5. Fontelles M J. Bioestatística aplicada à pesquisa experimental. Livraria da Física, São Paulo, 2012.

6. Chaves EC, Sarges NA, Santos MIPO. Impacto da hospitalização na independência funcional de idosos com doenças cardiovasculares. J Nurs Health [Internet]. 2014 [cited 2016 Jul 16];4(2):110-22. Available from: https://periodicos.ufpel.edu.br/ ojs2/index.php/enfermagem/article/view/4426/391 2

7. Lima Jr JRM, Sardinha AHL, Goncalves LHT, Coutinho NPSC, Pasklan ANP, Santos MAS. Cuidados de enfermagem e satisfação de idosos hospitalizados. Mundo Saúde [Internet]. 2015 [cited 2016 Jul 16];39(4):419-32. Available from: http://www.saocamilo-sp. $\mathrm{br} / \mathrm{pdf} / \mathrm{mundo}$ saude/155572/A03.pdf

8. Silva W, Fernandes AM, Silva JKB, Rodrigues MMD, Oliveira JS. Perfil de idosos hospitalizados em uma unidade de clínica de um hospital universitário. Anais CIEH [Internet]. 2015 [cited 2016 Jul 16];2(1). Available from: http://www.editorarealize.com.br/ revistas/cieh/trabalhos/trabalho_ev040_md2_sa2_id1734_14072015111407.pdf

9. Brasil. Instituto Brasileiro de Geografia e Estatística. Síntese dos indicadores sociais: uma análise das condições de vida da população brasileira [Internet]. 2015 [cited 2016 Sep 22]. Available from: biblioteca.ibge.gov.br/visualizacao/livros/liv95011.pdf

10. Correa AD, Marques IAB, Martinez MC, Laurino PS, Leão ER, Chimentão DMN. The implementation of a hospital's fall management protocol: results of a four-year follow-up. Rev Esc Enferm USP [Internet]. 2012 [cited 2016 Jul 16];46(1):67-74. Available from: http://www.scielo.br/pdf/reeusp/v46n1/en_v46n1a09.pdf

11. Nanda Internacional. Diagnósticos de enfermagem da NANDA: definições e classificação 2015 - 2017. Porto Alegre: Artmed, 2015.

12. Silva MCL, Polese JC, Starling JMP, Pereira LSM. Caracterização da clínica e motora-funcional de idosos hospitalizados pós Acidente Vascular Cerebral. Rev Neurociencenc [Internet]. 2014 [cited 2016 Jul 16];22(3):337-43. Available from: http://www. revistaneurociencias.com.br/edicoes/2014/2203/Original/940original.pdf

13. Castro VC, Borgh AC, Mariano PP, Fernandes CAM, Mathias, TAF, Carreira, L. Perfil de internações hospitalares de idosos no âmbito do Sistema Único de Saúde. Rev Rene [Internet]. 2013 [cited 2016 Jul 16];14(4):791-800. Available from: http://www. revistarene.ufc.br/revista/index.php/revista/article/viewFile/1269/pdf

14. Luzia MF, Victor MAG, Lucena AF. Diagnóstico de enfermagem Risco de quedas: prevalência e perfil clínico de pacientes hospitalizados. Rev Latino-Am Enfermagem [Internet]. 2014 [cited 2016 Jul 16];22(2):262-8. Available from: http://www.scielo.br/ pdf/rlae/v22n2/pt_0104-1169-rlae-22-02-00262.pdf

15. Geib LTC. Determinantes sociais da saúde do idoso. Ciênc Saúde Colet [Internet]. 2012 [cited 2016 Jul 16];17(1):123-33. Available from: http://www.scielo.br/pdf/csc/v17n1/a15v17n1.pdf

16. Pereira EEB, Souza, ABF, Carneiro SR, Sarges, ESNF. Funcionalidade global de idosos hospitalizados. Rev Bras Geriatr Gerontol [Internet]. 2014 [cited 2016 Jul 16];17(1):165-76. Available from: www.scielo.br/pdf/rbgg/v17n1/1809-9823-rbgg-17- 01-00165. pdf

17. Santana DF, Reis HFC, Ezequiel, DJS, Ferraz, DD. Perfil funcional, sociodemográfico e epidemiológico de idosos hospitalizados por fratura proximal de fêmur. Rev Kairós Gerontol [Internet]. 2015 [cited 2016 Jul 16];18(1):217-34. Available from: revistas. pucsp.br/index.php/kairos/article/download/26111/18745

18. Coutinho MLN. Perfil sociodemográfico e processo de hospitalização de idosos atendidos em um hospital de emergências. Rev Rene [Internet] 2015 [cited 2016 Jul 16];16(6)908-1005. Available from: http://www.periodicos.ufc.br/index.php/rene/article/ viewFile/2888/2250

19. Oliveira AS, Trevizan PF, Bestetti MLT, Melo RC. Fatores ambientais e risco de quedas em idosos: revisão sistemática. Rev Bras Geriatr Gerontol [Internet]. 2014 [cited 2016 Jul 16];17(3):637-45. Available from: http://www.scielo.br/pdf/rbgg/v17n3/18099823-rbgg-17-03-00637.pdf

20. Abreu HCA, Reiners AAO, Azevedo RCS, Silva AMC, Abreu DROM, Oliveira AD. Incidence and predicting factors of falls of older inpatients. Rev Saúde Pública [Internet]. 2015 [cited 2016 Jul 16];49:37. Available from: http://www.scielo.br/pdf/rsp/ v49/0034-8910-rsp-S0034-89102015049005549.pdf 
21. Mansur AP, Favarato D. Trends in mortality rate from cardiovascular disease in Brazil, 1980-2012. Arq Bras Cardiol [Internet]. 2016 [cited 2016 Jul 16];107(1):20-5. Available from: http://www.scielo.br/pdf/abc/v107n1/0066-782X-abc-20160077.pdf

22. Piuvezam G, Medeiros WR, Costa AV, Emerenciano FF, Santos RC, Seabra DS. Mortality from cardiovascular diseases in the elderly: comparative analysis of two five-year periods. Arq Bras Cardiol [Internet]. 2015 [cited 2016 Jul 16]. Available from: http:// www.scielo.br/pdf/abc/2015nahead/pt 0066-782X-abc-20150096.pdf

23. Xin W, Lin Z, Li X. Orthostatic hypotension and the risk of congestive heart failure: a meta- analysis of prospective cohort studies. PLoS One [Internet]. 2013 [cited 2016 Jul 16];13(8):5. Available from: http://journals.plos.org/plosone/article?id=10.1371/ journal.pone.0063169

24. Silva MRV, Dick NRM, Martini AC. Incidência de úlcera por pressão como indicador de qualidade na assistência de enfermagem. Rev Enferm UFSM [Internet]. 2012 [cited 2016 Jul 16];2(2):339-46. Available from: http://periodicos.ufsm.br/reufsm/article/ view/5238/3758

25. Wilson R, Hebert LE, Scherr PA, Dong X, Leurgens SE, Evans DA. Cognitive decline after hospitalization in a community population of older persons. Neurology [Internet]. 2012 [cited 2016 Sep 22]. Available from: http://www.neurology.org/content/ early/2012/03/21/WNL.0b013e31824d5894

26. Zaitune MPA, Barros MBA, Lima MG, César CLG, Carandina L, Goldbaum M et al. Fatores associados ao tabagismo em idosos: Inquérito de Saúde no Estado de São Paulo (ISA-SP). Cad Saúde Pública [Internet]. 2012 [cited 2016 Jul 16];28(3):583-96. Available from: http://www.scielo.br/pdf/csp/v28n3/18.pdf

27. Andrade AG. Alcoolismo na terceira idade[Internet]. 2015[cited 2016 Sep 22]. Available from: http://www.cisa.org.br/ artigo/5915/-alcoolismo-na-terceira-idade.php

28. Silva R, Schmidt OF, Sargeele S. Polifarmácia em idosos. Rev AMRIGS [Internet]. 2012 [cited 2016 Jul 16];56(2)164-74. Available from: http://www.amrigs.org.br/revista/56-02/revis.pdf

29. Rede Brasileira De Enfermagem e Segurança Do Paciente. REBRAENSP. Estratégias para a segurança do paciente: manual para profissionais da saúde. Porto Alegre: EDIPUCRS; 2013.

30. Sung YH, Cho MS, Kwon IG, Jung YY, Song MR, Kim K, et al. Evaluation of falls by inpatients in an acute care hospital in Korea using the Morse Fall Scale. Inter Journal of Nursing Practice [Internet] 2014 [cited 2016 Jul 16];20(5):510-7. Available from: http:// onlinelibrary.wiley.com/doi/10.1111/ijn.12192/abstract

31. Laguna-Parras JM, Arrabal-Orpez MJ, Zafra-López F, García-Fernández FP, Carrascosa-Corral RR, Carrascosa-García ML, et al. Incidencia de caídas en un hospital de nivel 1: factores relacionados. Gerokomos [Internet]. 2011 [cited 2015 Sep 30];22(4):167-73. Available from: http://scielo.isciii.es/pdf/geroko/v22n4/comunicacion3.pdf

32. REMOR, CP. Análise dos fatores de risco para queda de adultos nas primeiras 48 horas de hospitalização. Rev Gaúcha Enferm [Internet] 2014 [cited 2016 Jul 16];35(4):28-34. Available from: http://www.scielo.br/pdf/rgenf/v35n4/pt_1983-1447-rgenf-35-04-00028.pdf 